\title{
Improved procedure for the $\alpha$-Arylation of chromanones by O-Protected ortho-Bromophenols
}

\author{
Jorge L. O. Domingos, ${ }^{1}$ Diego Alonso, ${ }^{2}$ Carmem Nájera, ${ }^{* 2}$ Paulo R. R. Costa ${ }^{\star 1}$
}

${ }^{1}$ Laboratório de Química Bioorgânica, Núcleo de Pesquisas de Produtos Naturais. Centro de Ciências da Saúde, Bloco H, Universidade Federal do Rio de Janeiro, RJ 21941-590, Brazil. ${ }^{2}$ Departamento de Química Orgánica and Instituto de Síntesis Orgánica (ISO), Facultad de Ciencias,Universidad de Alicante, Apartado 99, E-03080 Alicante, Spain

*e-mail: prrcosta2011@gmail.com ; cnajera@ua.es

Keywords: $\alpha$-arylations, $P d_{2}(d b a)_{3}$, palladacycles

\section{INTRODUCTION}

In recent years some procedures for the $\alpha$-arylation of ketones appeared in the literature, allowing the formation of secondary, tertiary and even quaternary centers. However, only few examples on the use of ortho-substituted arylhalides have been described. ${ }^{1}$

As part of a project aiming the synthesis of isoflavonoids, we report herein a study on the $\alpha$ arylation of chromanone 1a and deoxi-chromanone $\mathbf{1 b}$ by ortho-bromophenol derivatives $\mathbf{2 a - c}$.

Figure 1. Ketones and ortho-bromophenol derivatives.<smiles>[X]c1ccccc1C(=O)CC</smiles><smiles>[R]Oc1ccccc1Br</smiles>
a, $\mathrm{R}_{1}=\mathrm{Me}$

b, $R_{1}=B n$

c, $\mathrm{R}_{1}=\mathrm{MOM}$

\section{RESULTS AND DISCUSSION}

The $\alpha$-arylations studied are shown in Scheme 1, Table 1. We start our study with the reaction between $1 a$ by $2 a$ and a clean transformation of $2 a$ was observed under microwave irradiation, leading to $3 \mathbf{a}$ (entry 1 ). The $\alpha$-arylation goes very well even for more sterically hindered ortho-bromophenols $\mathbf{2 b}$ and 2c (entries 2 and 3). The same trend was observed in the reactions between $\mathbf{1 b}$ and $\mathbf{2 a - c}$ (entries 4-6).

We also used the oxime-derived palladacycle precatalyst $\mathbf{5}$, synthesized by the Spanish group and previously used in several carbon-carbon bondforming reactions in organic solvents as well as in neat water or aqueous solvents. ${ }^{2}$ As shown in entry 7 , a complete conversion was also observed in this case.

In contrast with the reported procedures under thermal conditions, which requires more than $2 \mathrm{~h}$ to completion, under microwave irradiation a total conversion of $\mathrm{O}$-protected ortho-bromophenols was achieved after $1 \mathrm{~h}$ of reaction. In addition, products of $\alpha, \alpha$-diarylation, which are side products in these reactions, could not be detected in the crude product. The chemical yield of these reactions will be reported soon.

Scheme 1. Palladium-catalyzed $\alpha$-Arylation of 1 by 2 .
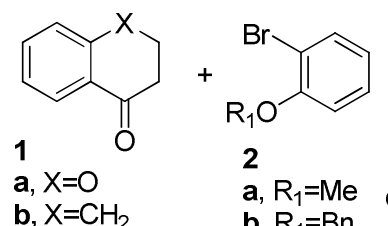

\section{catalyst} microwave<smiles>[X]c1ccccc1C(=O)C1CCCCC1[R]</smiles>

b, $\mathrm{X}=\mathrm{CH}_{2}$ b, $\mathrm{R}_{1}=\mathrm{Bn}$

c, $\mathrm{R}_{1}=\mathrm{MOM}$

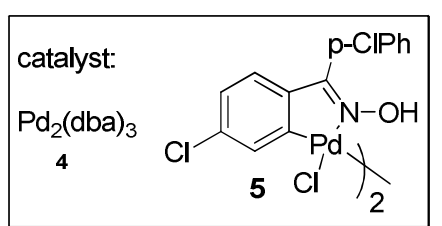

a, $X=O, R_{1}=M e$

b, $X=O, R_{1}=B n$

c, $X=O, R_{1}=$ MOM

d, $\mathrm{X}=\mathrm{CH}_{2}, \mathrm{R}_{1}=\mathrm{Me}$

e, $\mathrm{X}=\mathrm{CH}_{2}, \mathrm{R}_{1}=\mathrm{Bn}$

f, $\mathrm{X}=\mathrm{CH}_{2}, \mathrm{R}_{1}=\mathrm{MOM}$
Table 1. Yields and main conditions for the reactions shown in Scheme 1.

\begin{tabular}{|c|c|c|c|c|}
\hline entry & $\mathbf{1}$ & $\mathbf{2}$ & $\mathbf{3}$ & conversion \\
\hline 1 & $\mathbf{1 a}$ & $\mathbf{a}$ & $\mathbf{3 a}$ & $100 \%$ \\
\hline 2 & $\mathbf{1 a}$ & $\mathbf{b}$ & $\mathbf{3 b}$ & $100 \%$ \\
\hline 3 & $\mathbf{1 a}$ & $\mathbf{C}$ & $\mathbf{3 c}$ & $100 \%$ \\
\hline 4 & $\mathbf{1 b}$ & $\mathbf{a}$ & $\mathbf{3 d}$ & $100 \%$ \\
\hline 5 & $\mathbf{1 b}$ & $\mathbf{b}$ & $\mathbf{3 e}$ & $100 \%$ \\
\hline 6 & $\mathbf{1 b}$ & $\mathbf{c}$ & $\mathbf{3 f}$ & $100 \%$ \\
\hline 7 & $\mathbf{1 b}$ & $\mathbf{a}$ & $\mathbf{3 d}$ & $100 \%$ \\
\hline
\end{tabular}

*2.5 mol\% of $\mathrm{Pd}_{2}(\mathrm{dba})_{3} 4$ or palladacycle $5,10 \% \mathrm{~mol}^{t} \mathrm{Bu}_{3} \mathrm{PHBF}_{4}$, $20 \%$ mol TBAB, 1 eq. bromo-phenol 2, 2 eq. ketone 1,2 eq. $\mathrm{KOH}, 120^{\circ} \mathrm{C}, 80 \mathrm{~W}, 1 \mathrm{~h}$, Dioxane/water (4:1). Conversion measured by GC/MS. The reaction mixtures were degassed to prevent hydroxylation at the $\alpha$-position in the products.

\section{CONCLUSION}

The procedure described is usefull to prepare flavonoids,

\section{ACKNOWLEDGEMENTS}

CAPES (Brazil), DGU (Spain), FAPERJ and CNPq.

\section{REFERENCES}

${ }^{1}$ Bellina, F., Rossi, R., Eur. J.Org. Chem. 2010, 1339 and references cited.

2 Botella, L.; Nájera, C., J. Org. Chem.. 2005, 70, 4360. 